\title{
Docosahexaenoic acid associated vitamin $E$ in the diluent for cryopreservation of goat semen
}

\section{Ácido docosahexaenoico associado à vitamina $\mathrm{E}$ no meio diluidor para criopreservação de sêmen caprino}

\author{
Caline Santana da França; Poliana Almeida Bezerra²; Claudinéia Silva Mendes; \\ Laiara Fernandes Rocha'; Ana Lucia Almeida Santana ${ }^{3}$; Rosileia Silva Souza4; \\ Rodrigo Freitas Bittencourt5; William Morais Machado ${ }^{6}$; Paola Pereira das Neves \\ Snoeck ${ }^{7}$; Larissa Pires Barbosa ${ }^{3 *}$
}

\section{Highlights}

The DHA did not promote any improvement in the quality of post-thawed semen.

The addition of DHA to the seminal diluent preserved sperm kinetics.

The addition of DHA to the seminal diluent did not improve the membrane integrity.

\begin{abstract}
The objective of this study was to evaluate the effect of and determine the optimum level of inclusion of docosahexaenoic acid (DHA) in the diluent for goat semen cryopreservation. Five Boer males underwent semen collection, totaling 10 viable collections per animal. After evaluation, the ejaculates were pooled and fractionated in Tris-yolk medium with the addition of 0; 30; 45; or $60 \mathrm{ng} \mathrm{mL}^{-1}$ of DHA and $0.4 \mathrm{mmol}$ of alphatocopherol (Vitamin E). The semen was cryopreserved in a freezing machine (TK $3000^{\mathrm{TM}}$ ) and placed in a cryogenic cylinder for subsequent analysis. Data were evaluated by regression analysis at $5 \%$ significance. There were no differences $(P>0.05)$ in sperm kinetic parameters evaluated by computer assisted sperm analysis: total motility $(79.17 \pm 17.31 \%)$, progressive motility $(14.04 \pm 5.73 \%)$, curvilinear speed $(58.82 \pm$ $6.35 \mu \mathrm{m} / \mathrm{s})$, progressive linear speed $(22.49 \pm 3.63 \mu \mathrm{m} / \mathrm{s})$, mean path speed $(35.17 \pm 4.52 \mu \mathrm{m} / \mathrm{s})$, linearity $(38.69$ $\pm 5.79 \%)$, rectilinearity $(63.99 \pm 6.64 \%)$, and oscillation index $(59.68 \pm 2.99 \%)$. There were no differences $(P$

1 Mestres em Ciência Animal, Programa de Pós-Graduação em Ciência Animal, Universidade Federal do Recôncavo da Bahia, UFRB, Cruz das Almas, BA, Brasil. E-mail: francacs@outlook.com; caumendes18@gmail.com; laiarafr@gmail.com

2 Discente do Curso de Graduação em Medicina Veterinária, UFRB, Cruz das Almas, BA, Brasil. E-mail: polialmeida5@ gmail.com

3 Profas Dras, UFRB, Cruz das Almas, BA, Brasil. E-mail: zootecana@gmail.com; larissa@ufrb.edu.br

${ }^{4}$ Bolsista do Programa Nacional de Pós-Doutorado, Programa de Pós-Graduação em Ciência Animal, UFRB, Cruz das Almas, BA, Brasil. E-mail: rosileiasouza@hotmail.com

5 Prof. Dr., Universidade Federal da Bahia, UFBA, Salvador, BA, Brasil. E-mail: rfbvet1@gmail.com

${ }^{6}$ Discente do Curso de Doutorado do Programa de Pós-Graduação em Ciência Animal, Universidade Estadual de Santa Cruz, UESC, Ilhéus, BA, Brasil. E-mail: william.moraiss@hotmail.com

7 Profa ${ }^{\text {Dra }}$, UESC, llhéus, BA, Brasil. E-mail: paolasnoeck@gmail.com

* Author for correspondence
\end{abstract}

Received: May 20, 2020 - Approved: Nov. 03, 2020 
$>0.05$ ) found from the membrane functional integrity test for reactive spermatozoa (69.66 $\pm 9.76 \%)$, plasma and acrosomal membrane integrity of intact spermatozoa (29.86 $\pm 7.57 \%)$, mitochondrial potential of Class I cryopreserved goat semen $(72.75 \pm 9.81 \%)$, and chromatin compaction of intact chromatin (96.87 $\pm 4.37 \%)$. Thus, the inclusion of up to $60 \mathrm{ng} \mathrm{mL}^{-1}$ of DHA did not promote any improvement in the seminal quality parameters of post-thawed goat semen.

Key words: Computer assisted sperm analysis. Lipids. Omega 3. Plasma membrane. Spermatozoa.

\section{Resumo}

O estudo teve como objetivo avaliar o efeito e determinar o melhor nível de inclusão de ácido docosahexaenoico (DHA) no diluidor para criopreservação de sêmen caprino. Cinco machos Boer foram submetidos a coletas de sêmen, totalizando 10 coletas viáveis por animal. Após avaliação, os ejaculados foram agrupados (pool) e fracionados em meio Tris gema, acrescido de 0; 30; 45 e 60ng mL-1 de DHA e 0,4mmol de alfa-tocoferol. O sêmen foi criopreservado em máquina de congelamento TK $3000^{\circ}$ e acondicionado em botijão criogênico para posterior análise. Os dados foram avaliados por análise de regressão a $5 \%$ de significância. Não houve diferença $(P>0,05)$ nos parâmetros cinéticos espermáticos avaliados pela análise assistida por computador: motilidade total $(79,17 \pm 17,31 \%)$, motilidade progressiva $(14,04 \pm 5,73 \%)$, velocidade curvilínea $(58,82 \pm 6,35 \mu \mathrm{m} / \mathrm{s})$, velocidade linear progressiva $(22,49 \pm 3,63 \mu \mathrm{m} / \mathrm{s})$, velocidade média do caminho $(35,17 \pm 4,52 \mu \mathrm{m} / \mathrm{s})$, linearidade $(38,69 \pm 5,79 \%)$, retilinearidade $(63,99 \pm 6,64 \%)$ e índice de oscilação $(59,68 \pm 2,99 \%)$. Não foram encontradas diferenças $(P>0,05)$ no teste de integridade funcional da membrana para espermatozoides reativos $(69,66 \pm 9,76 \%)$, integridade plasmática e membrana acrossomal dos espermatozoides intactos $(29,86 \pm 7,57 \%)$, potencial mitocondrial do sêmen caprino de classe I (72,75 $\pm 9,81 \%$ ) e compactação da cromatina intacta $(96,87 \pm 4,37 \%)$. A inclusão de até $60 n g \mathrm{~mL}^{-1}$ de DHA não promoveu melhora nos parâmetros de qualidade seminal de caprinos pós-descongelamento.

Palavras-chave: CASA. Espermatozoides. Lipídios. Membrana plasmática. Ômega 3.

\section{Introduction}

The plasma membrane is a highly dynamic structure that surrounds the entire sperm surface; however, although it is continuous, it differs regionally and its lipid composition is a major determinant of cryopreservation capacity. In different mammalian species, up to $60 \%$ of the phospholipid bound to the total cell fatty acids are long chain polyunsaturated fatty acids (PUFAs), especially docosahexaenoic acid (DHA) (Flesh \& Gadella, 2000). The availability of DHA is essential for sperm tail motility because it enables greater membrane fluidity (Towhidi, Zeinoaldini, Ardebili, Davachi, \& Nasiri, 2013). Human (González-Ravina et al., 2018) and animal (Losano et al., 2018) studies have shown that the plasma membrane DHA concentration is positively associated with improved sperm motility, which is related to the presence of doubles links in the DHA.

The addition of a source of PUFAs to the diluent is beneficial to sperm and provides greater protection during the cryopreservation process. Increased fluidity and flexibility of the plasma membrane increases the freezing tolerance and prevents the rupture of the 
sperm cell membrane by the formation of ice crystals during the freezing and thawing process (Ansari, Towhidi, Shahrbabak, \& Bahreini, 2012).

Previous studies have shown the beneficial effects of in vitro supplementation with sources of PUFAs in the freezing medium, such as DHA-rich fish oil (Del Valle, Souter, \& Maxwell, 2013; Machado et al., 2018), alphalinolenic acid (Nasiri, Towhidi, \& Zeinoaldini, 2012; Kaka et al., 2015), and linoleic acid (Takahashi, Itoh, Nishinomiya, \& Manabe, 2012). These additives are promising alternatives as components in seminal diluents.

However, the inclusion of a PUFA source must be associated with an antioxidant owing to the susceptibility of these acids to the action of reactive oxygen species (ROS) because of the presence of double bonds. Thus, the present study aimed to evaluate the effect of and determine the best level of inclusion of DHA in diluent for goat semen cryopreservation.

\section{Material and Methods}

\section{Experiment location and ethic committee}

The experiment was undertaken at Agropecuária farm BANTU in Itaberaba / Bahia, located at $12^{\circ} 31^{\prime} 39^{\prime \prime} \mathrm{S}$ and $40^{\circ} 18^{\prime} 25^{\prime \prime}$ $\mathrm{W}$ and seminal analyses performed at the Animal Reproduction Laboratory of the Center for Agricultural, Environmental and Biological Sciences at the Federal University of Recôncavo of Bahia in Cruz das Almas - BA and the Animal Reproduction Laboratory of Santa Cruz State University in Ilhéus - BA.

The project was approved by the Animal Use Ethics Committee of the Federal University of Recôncavo of Bahia, under protocol number 23007.011081/2017-65.

Animals, maneuver and experimental distribution

Were used five adult Boer males, with an average age of $33 \pm 18$ months, selected by previous andrological examination, following the norms of the Colégio Brasileiro de Reprodução Animal [CBRA], (2013). The animals were maintained in an intensive production system, received Buffel grass hay (Cenchrus ciliaris L.) and a concentrated mixture formulated to meet the nutritional requirements of the animals, and free access to water.

Seminal collections were performed by the artificial vagina method, using a female in estrus as a dummy, with a 24-h interval between collections. In total, 10 viable collections were obtained. After each collection, the ejaculates were evaluated for physical aspects (i.e., seminal volume and appearance, sperm vortexing, progressive sperm motility, and sperm vigor) under phase differential interference microscopy (Olympus ${ }^{\mathrm{TM}}$, Tokyo, Japan). The ejaculates with motility $\geq 70 \%$ and sperm vigor $\geq 3$ were pooled in one group and a sample was taken to evaluate the morphology and determine sperm concentration (CBRA, 2013).

After pooling, the samples were evaluated for progressive sperm motility and sperm vigor and, when values were found within the standards required by CBRA (2013), were diluted in Tris-yolk medium, and sequentially fractionated into four groups (G) containing different DHA levels. These groups were G1-0ng mL-1, G2-30ng mL-1, G3- 
45ng $\mathrm{mL}^{-1}$, and G4-60ng $\mathrm{mL}^{-1}$, plus $0.4 \mathrm{mmol}$ alpha-tocopherol (Vitamin E, Sigma-Aldrich ${ }^{\mathrm{TM}}$, Brazil), and diluted in $0.05 \%$ ethanol solution. The stock DHA solution (Sigma-Aldrich ${ }^{\mathrm{TM}}$ ) was calculated based on its molecular weight of $328.49 \mathrm{~g} \mathrm{~mol}^{-1}$ and diluted in $100 \mathrm{~mL}$ of $0.05 \%$ ethanol solution.

\section{Variables evaluated and methodologies applied}

After fractionation of the experimental groups, the semen was packed in $0.25 \mathrm{~mL}$ straws, using a concentration of $150 \times 10^{6}$ sperm per dose, which were cryopreserved in a cryopreservation machine (TK $3000^{\mathrm{TM}}$ ), following a positive curve of $0.25^{\circ} \mathrm{C} / \mathrm{min}$ from $32^{\circ} \mathrm{C}$ until reaching $+5^{\circ} \mathrm{C}$ and a negative curve divided into two phases: freeze from $+5^{\circ} \mathrm{C}$, in a speed of $10^{\circ} \mathrm{C} / \mathrm{min}$ and $5^{\circ} \mathrm{C} / \mathrm{min}$ until reaching $-120^{\circ} \mathrm{C}$, then dipped in liquid nitrogen at $-196^{\circ} \mathrm{C}$ and stored in a cryogenic cylinder $\left(-196^{\circ} \mathrm{C}\right)$. After thawing, sperm motility and vigor, sperm kinetics, plasma membrane functional integrity, plasma and acrosomal membrane structural and functional integrity, and mitochondrial activity and chromatin compaction were evaluated. For motility and vigor evaluation, the samples were thawed in a water bath at $37^{\circ} \mathrm{C}$ for 30 s and a $10 \mu \mathrm{L}$ sample was analyzed by microscopy (Olympus ${ }^{\mathrm{TM}}$, Tokyo, Japan).

Sperm kinetics were evaluated by computer-assisted sperm analysis (CASA, $\mathrm{SCA}^{\mathrm{TM}}$ ). The samples were diluted again to obtain a final sperm concentration of $50 \times 10^{6 /}$ $\mathrm{mL}$. The standards used for the adjustment of the equipment were based on the SCATM program recommendations (Microptics S.L, v. 5.2, Barcelona, Spain) for goat sperm analysis: 25 images/s at $25 \mathrm{~Hz}$; captured particle size between 3 and $70 \mu \mathrm{m} / \mathrm{m}^{2}$; and sperm considered slow $<10 \mu \mathrm{m} / \mathrm{s}$, average 45 to $75 \mu \mathrm{m} / \mathrm{s}$, and fast above $75 \mu \mathrm{m} / \mathrm{s}$. The following parameters were evaluated: total motility (TM, $\%)$, progressive motility (PM, \%), average path velocity (VAP, $\mu \mathrm{m} / \mathrm{s})$, Curvilinear velocity (VCL, $\mu \mathrm{m} / \mathrm{s})$, progressive linear velocity (VSL, \%), rectilinearity (STR, \%), linearity (LIN, \%), and oscillation index (WOB, \%).

The functional integrity of the plasma membrane was evaluated by the HypoOsmotic Swelling (HOST) using $1 \mathrm{~mL}$ of fructose-containing hypo-osmotic solution (100 mOsmol $/ \mathrm{kg}$ ) plus $10 \mu \mathrm{L}$ of semen from each sample and incubated for $30 \mathrm{~min}$ in a water bath at $37^{\circ} \mathrm{C}$. To quantify the HOST, 200 sperm cells were classified by phase contrast microscopy at 1000X magnification, under immersion, for the presence or absence of a folded tail. The number of HOST-reactive sperm was calculated by the formula: HOST (\%) $=(\%$ tail changes after HOST $)-(\%$ tail changes before HOST).

The structural integrity of the plasma and acrosomal membranes were assessed using a fluorescence microscope (400X; Olympus $^{\mathrm{TM}} \mathrm{BX}$ 51) after sperm staining with carboxy fluorescein diacetate (CFDA) and propidium iodide (PI). CFDA staining was assessed using the standard fluorescein filter set, whereas PI staining was assessed using the standard rhodamine filter set, in 200 sperm per sample.

Mitochondrial sperm activity was assessed by incubating $20 \mu \mathrm{L}$ of each thawed sample in $20 \mu \mathrm{L}$ of $3,3^{\prime}$-diaminobenzidine (Sigma-Aldrich ${ }^{\mathrm{TM}}$ ) and $1 \mathrm{mg} / \mathrm{mL}$ phosphate buffered saline at $37^{\circ} \mathrm{C}$ for $60 \mathrm{~min}$ in the dark. After incubation, smears were made that were fixed in $10 \%$ formaldehyde for $10 \mathrm{~min}$, 
washed in distilled water, and air-dried under light protection. Under a phase differential interference microscope (Olympus ${ }^{\mathrm{TM}}$, Tokyo, Japan), under 1000X magnification, 200 sperm per slide were evaluated and classified based on the intermediate dye deposition, i.e., Class I (fully colored intermediate part); Class || ( $\geq$ $50 \%$ of the intermediate part colored); Class III ( $\leq 50 \%$ of the intermediate part colored), and Class IV (no intermediate part stained).

For the sperm chromatin compaction analysis, protocol Beletti and Mello (2004) was used. Smears were made with an aliquot from each thawed cane. After drying at room temperature, the smears were fixed in Carnoy's solution for $1 \mathrm{~min}$ and then in $70 \%$ ethanol for 3 min. Hydrolysis with $4 \mathrm{~N}$ hydrochloric acid was performed for $15 \mathrm{~min}$, washed in distilled water, and dried at room temperature. To stain the smears, a drop of $0.025 \%$ toluidine blue dye solution in Mcllvaine buffer, $\mathrm{pH}$ 4.0, was deposited between the slide and coverslip. We evaluated 500 sperm per slide with a light microscope under a 1000X immersion objective and classified them as intact chromatin (light blue stained head region) or fragmented chromatin (head region stained dark blue or violet). All tests were performed by the same observer and were subjectively evaluated.

\section{Statistical analysis}

A completely randomized design was used. Data were evaluated for normality using the Shapiro-Wilk test. The variables with normal distribution were analyzed by analysis of variance (ANOVA) and the regression analysis and non-parametric data were performed by the Kruskal-Wallis test at $5 \%$ significance (SPSS Statistics, 2015).

Results

There was no difference in sperm kinetic parameters evaluated $(P>0.05)$ (Table $1)$, nor in the membrane functional integrity test (HOST) of the cryopreserved goat semen with different DHA levels in the diluent, with averages of $69.66 \pm 9.76 \%(P=0.441)$ for the reactive spermatozoa and $30.01 \pm 8.66 \%$ for the non-reactive spermatozoa $(P=0.660)$ (Table 2). 
Table 1

Sperm kinetic values evaluated by the computer assisted sperm analysis (CASA) of sperm movement for cryopreserved goat semen with the addition of different docosahexaenoic acid (DHA) levels

\begin{tabular}{lccccc|} 
Variables & \multicolumn{5}{c}{ DHA levels $\left(\mathrm{ng} \mathrm{mL}^{-1}\right)$} \\
\cline { 2 - 6 } & $0(\mathrm{C})$ & 30 & 45 & 60 & Mean \\
\hline TM $(\%)^{1}$ & $80.50 \pm 19.25$ & $81.90 \pm 19.75$ & $78.80 \pm 8.95$ & $75.50 \pm 21.30$ & $79.17 \pm 17.31$ \\
PM $(\%)^{2}$ & $14.11 \pm 5.39$ & $14.14 \pm 5.05$ & $13.58 \pm 6.17$ & $14.36 \pm 6.31$ & $14.04 \pm 5.73$ \\
VCL $(\mu \mathrm{m} / \mathrm{s})^{2}$ & $58.08 \pm 8.14$ & $60.04 \pm 6.28$ & $56.15 \pm 2.72$ & $61.04 \pm 8.29$ & $58.82 \pm 6.35$ \\
VSL $(\mu \mathrm{m} / \mathrm{s})^{2}$ & $22.46 \pm 4.07$ & $22.81 \pm 3.17$ & $21.68 \pm 3.57$ & $23.02 \pm 3.71$ & $22.49 \pm 3.63$ \\
VAP $(\mu \mathrm{m} / \mathrm{s})^{2}$ & $34.62 \pm 5.79$ & $35.93 \pm 4.80$ & $33.28 \pm 2.28$ & $36.88 \pm 5.24$ & $35.17 \pm 4.52$ \\
LIN $(\%)^{2}$ & $38.74 \pm 4.97$ & $38.03 \pm 4.20$ & $40.01 \pm 8.24$ & $37.98 \pm 5.76$ & $38.69 \pm 5.79$ \\
STR $(\%)^{2}$ & $65.00 \pm 5.98$ & $63.64 \pm 6.23$ & $64.64 \pm 7.34$ & $62.68 \pm 7.04$ & $63.99 \pm 6.64$ \\
WOB $(\%)^{2}$ & $59.47 \pm 2.82$ & $59.75 \pm 2.56$ & $59.11 \pm 3.74$ & $60.40 \pm 2.87$ & $59.68 \pm 2.99$
\end{tabular}

$\mathrm{C}=$ Control; $\mathrm{TM}=$ Total Mobility; PM = Progressive Mobility; VCL = Curvilinear velocity; VSL = Progressive Linear Velocity; VAP = Average Path Velocity; LIN = Linearity; STR = Rectilinearity; WOB = Oscillation Index or Wobble $(\mathrm{RS} / \mathrm{CS}) \times 100 .{ }^{1}$ The data refers to median \pm interquartile range and were evaluated through the non-parametric Kruskal-Wallis test at $5 \%$ significance. ${ }^{2}$ The data refers to means \pm standard deviation and were evaluated by ANOVA and regression analysis at $5 \%$ significance. There was no statistical difference $(P>0.05)$.

Table 2

Hypo-osmotic test of cryopreserved goat semen in different docosahexaenoic acid (DHA) levels in the diluent

\begin{tabular}{lccccc}
\hline \multirow{2}{*}{ HOST (\%) } & \multicolumn{5}{c}{ Levels of docosahexaenoic acid (DHA) $\left(\mathrm{ng} \mathrm{mL}^{-1}\right)$} \\
\cline { 2 - 5 } & $0(\mathrm{C})$ & 30 & 45 & 60 & Mean \\
\hline Reactives & $67.45 \pm 7.01$ & $71.10 \pm 8.64$ & $68.00 \pm 12.05$ & $72.10 \pm 11.34$ & $69.66 \pm 9.76$ \\
\hline Non reactives & $32.55 \pm 7.06$ & $28.90 \pm 8.64$ & $30.40 \pm 8.86$ & $28.55 \pm 10.09$ & $30.01 \pm 8.66$
\end{tabular}

$\mathrm{C}=$ Control; HOST = Hypo-osmotic test. The data were evaluated by ANOVA and regression analysis at $5 \%$ significance. The data refer to the means \pm standard deviation. There was no statistical difference $(P>0.05)$.

There was no difference in the results found from the integrity test of plasmatic and acrosomal membrane evaluated by the 6-carboxyfluorescein diacetate/propidium iodide probes (CFDA/PI) of cryopreserved goat semen with different DHA levels in the diluent, with means of $29.86 \pm 7.57 \%(P=0.622)$ for intact spermatozoa, $48.39 \pm 7.95 \%(P=0.317)$ for injured spermatozoa, and $21.74 \pm 7.46 \%$ $(\mathrm{P}=0.854)$ for semi-injured spermatozoa $(\mathrm{P}=$ 0.635) (Table 3). 
Table 3

\section{Post-thawing analysis results of the plasmatic and acrosomal membrane after evaluation by epifluorescence CFDA/PI}

\begin{tabular}{lccccc} 
Integrity of & \multicolumn{5}{c}{ DHA levels $\left(\mathrm{ng} \mathrm{mL}^{-1}\right)$} \\
\cline { 2 - 6 } membrane (\%) & $0(\mathrm{C})$ & 30 & 45 & 60 & Mean \\
\hline Intact sperm & $30.82 \pm 7.71$ & $32.88 \pm 8.21$ & $28.70 \pm 10.75$ & $27.05 \pm 8.39$ & $29.86 \pm 7.57$ \\
\hline Injured sperm & $46.50 \pm 9.68$ & $44.77 \pm 8.75$ & $51.05 \pm 6.45$ & $51.27 \pm 6.94$ & $48.39 \pm 7.95$ \\
\hline Semi-injured sperm & $22.72 \pm 9.56$ & $22.33 \pm 10.61$ & $20.25 \pm 8.19$ & $21.66 \pm 8.50$ & $21.74 \pm 7.46$
\end{tabular}

$\mathrm{C}=$ Control. The data were evaluated by ANOVA and regression analysis at $5 \%$ significance. The data refers to means \pm standard deviation. There was no statistical difference $(P>0.05)$.

There was no difference in the results of the mitochondrial activity test in Classes I, II, III, and IV (P > 0.05) of the cryopreserved goat semen with different DHA levels in the diluent, with means of $72.75 \pm 9.81 \%(P=0.358), 10.93$ $\pm 4.64 \%(P=0.130), 9.83 \pm 5.11 \%(P=0.859)$, and $6.46 \pm 7.25 \%(P=0.745)$, respectively (Table 4).

\section{Table 4.}

Mitochondrial activity test of cryopreserved goat semen with different docosahexaenoic acid levels (DHA) in the diluent

\begin{tabular}{lccccc} 
Mitochondria (\%) & \multicolumn{5}{c}{ DHA levels $\left(\mathrm{ng} \mathrm{mL} \mathrm{mL}^{-1}\right)$} \\
\cline { 2 - 6 } & $0(\mathrm{C})$ & 30 & 45 & 60 & Mean \\
\hline Class I & $70.85 \pm 6.06$ & $73.44 \pm 14.64$ & $76.95 \pm 9.08$ & $69.77 \pm 9.48$ & $72.75 \pm 9.81$ \\
Class II & $11.70 \pm 2.88$ & $10.33 \pm 6.45$ & $8.65 \pm 4.27$ & $13.05 \pm 4.99$ & $10.93 \pm 4.64$ \\
Class III & $9.90 \pm 4.31$ & $9.77 \pm 6.19$ & $8.80 \pm 4.24$ & $10.88 \pm 5.73$ & $9.83 \pm 5.11$ \\
Class IV & $7.55 \pm 6.33$ & $6.44 \pm 7.18$ & $5.60 \pm 5.56$ & $6.27 \pm 9.96$ & $6.46 \pm 7.25$
\end{tabular}

$\mathrm{C}=$ Control. Class I = fully colored intermediate part; Class II $=\geq 50 \%$ of intermediate part colored; Class III $=\leq 50 \%$ of intermediate part colored; and Class IV = absence of coloring of intermediate part. The data were evaluated by ANOVA and regression analysis at $5 \%$ significance. The data refers to means \pm standard deviation. There was no significant difference $(P>0.05)$.

There was no differences obtained in the results of the chromatin compaction analysis $(P>0.05)$ of cryopreserved goat semen with different DHA levels in the diluent, with means of $96.87 \pm 4.37 \%(P=0.574)$ for intact chromatin and $2.95 \pm 2.40 \%(P=0.635)$ for fragmented chromatin (Table 5). 


\section{Table 5}

Sperm chromatin compaction analysis of cryopreserved goat semen with different docosahexaenoic acid levels (DHA) in the diluent

\begin{tabular}{|c|c|c|c|c|c|}
\hline \multirow{2}{*}{ Chromatin (\%) } & \multicolumn{5}{|c|}{ DHA levels (ng mL-1) } \\
\hline & $0(\mathrm{C})$ & 30 & 45 & 60 & Mean \\
\hline Intact $^{1}$ & $96.20 \pm 4.20$ & $97.20 \pm 2.80$ & $97.30 \pm 6.60$ & $96.80 \pm 3.90$ & $96.87 \pm 4.37$ \\
\hline Fragmented $^{2}$ & $2.62 \pm 2.11$ & $3.66 \pm 2.28$ & $2.86 \pm 3.05$ & $2.66 \pm 2.19$ & $2.95 \pm 2.40$ \\
\hline
\end{tabular}

\section{Discussion}

Despite a large number of studies showing a beneficial effect of adding DHA, or other sources of PUFAs, in sperm physical parameters (Ansari et al., 2012; Nasiri et al., 2012; Towhidi et al., 2013; Abdi-Benemar et al., 2015), the absence of effect of DHA inclusion in the seminal thinner in sperm physical parameters measured by CASA, noticed in this study, corroborates with other studies using the same source of fatty acids and in varying amounts, inferior or superior to the ones used in the present study (Aguiar et al., 2020). Besides, some studies even show the deleterious effect of including DHA in seminal diluting medium on sperm physical parameters (Kaka et al., 2017).

The discussion, to justify these different conclusions, was very well grounded by Ansari et al. (2012), when they spoke about how the positive effect of omega 3 fatty acid on sperm characteristics is probably related to an increase in DHA proportion in sperm membrane lipids and that the supplemented omega 3 fatty acid probably enhances PUFA proportion in sperm head and tail membrane which improves fluidity that is necessary for sperm motility. However, they also observed that after the cryopreservation process there was a significantly decrease in DHA percentage in both groups with and without addition of DHA in the seminal thinner and assumes as possible reasons the lipid peroxidation has been reported as being enhanced during cryopreservation of spermatozoa, as also, could be an increase in the amount of saturated fatty acids taken up or passively bound to the sperm membranes which would cause a decrease in the proportion of the long-chain polyunsaturated fatty acids, quoting a study performed by Maldjian et al. (2005).

Another possibility for the low percentages of CASA parameters obtained in the present study may be related to possible imbalances between ROS and the antioxidant concentration used during the freezing process, which may have compromised the physiology and viability of spermatic cells as discussed by Apriokur (2013). In addition, researchers (Dorado, Hidalgo, Muñoz \& Rodríguez, 2009) suggest that the freezing and thawing procedures decrease the kinetics of goat sperm, which were objectively measured by computerized methods.

The results for the membrane functional integrity test are in agreeance with those obtained from Machado et al. (2018) who used a citrate-egg yolk diluent enriched with 
fish oil levels for goat semen cryopreservation and did not obtain an improvement from the hyposmotic test. However, Abdi-Benemar et al. (2015) obtained better results for plasmatic membrane integrity (50.74 \pm 0.92\%) after supplementing the diluent with up to $0.30 \mathrm{~g}$ of fish oil as a EPA source and $150 \mu \mathrm{M}$ of vitamin $\mathrm{E}$ to cryopreserve the semen of breeding sheep. To justify these differences, it is possible to suggest the type of PUFA used (DHA and EPA) and maybe the amount of vitamin $E$ used in this study, quantities based on the study by Ansari et al. (2012).

The presence of DHA in the spermatic membrane increases cryogenic tolerance and maintains the physiological properties of the lipid bilayer (Kaka et al., 2015). However, the DHA combined with vitamin $\mathrm{E}$ in the present study was not effective in providing greater cryoresistance to goat semen, perhaps it had lower DHA incorporation in the plasmatic membrane of the spermatozoa, the liped profile of the sperm plasma membrane, after treatment, was not evaluated in the present study. Again, despite Ansari et al. (2012) affirming that the addition of omega 3 fatty acid with an antioxidant could improve freezing ability of goat semen via changing the lipid composition of sperm cell, it may have a significantly decrease of fatty acids in the sperm membrane. As previously mentioned, a possible reason of this decrease in the proportion of PUFA could be an increase in the amount of saturated fatty acids taken up or passively bound to the sperm membranes which would cause a decrease in the proportion of the PUFAs (Maldjian et al., 2005).

Towhidi et al. (2013) evaluated the incorporation of an omega 3 source in sheep semen diluent and observed that there was DHA incorporation in semen before freezing; however, after thawing, there was a significant decrease in concentration. This was caused by the excessive production of ROS during cryopreservation.

The results obtained from the integrity test of plasmatic and acrosomal membrane evaluated by the 6-carboxyfluorescein diacetate/propidium iodide probes (CFDA/PI) of cryopreserved goat semen with different DHA levels in the diluent were similar to each other. According to Towhidi et al. (2013), $99 \%$ of the DHA content is in the tail of the spermatozoa, not the head. This might exiplain the absence of improvement to acrosomal membrane damage in the present study.

The DHA incorporation benefits are mainly reflected in the increase of spermatozoa mobility by increasing membrane fluidity (Ansari et al., 2012). PUFAs create greater susceptibility of lipid peroxidation causing modifications in the spermatozoa plasmatic membrane during the cryopreservation process (Bucak et al., 2010). Therefore, the antioxidant system plays an important role in balancing ROS and antioxidant function, and a greater level of antioxidants may be beneficial when high PUFAs concentrations are used.

The mitochondrial potential has a strong correlation with tail energy potential and mobility of the cell; therefore, it is linked with fertility (Tsakmakidis, 2010) and with spermatic mobility (Marco-Jiménez et al., 2006). According to Cavalcante, Esper and Ferreira (2005), after thawing, the cytochemical activity index for Boer and Alpina breeds were $66.00 \%$ and $67.25 \%$, respectively, assuming that more than half of the mitochondria were active in the spermatozoa after thawing, which is compatible to supporting the spermatic mobility percentage when evaluated after thawing. 
There was no difference found from the chromatin compaction analysis, with these data showing that the cryopreservation protocol and diluent used, regardless of the DHA inclusion level, was efficient and did not promote DNA damage. According to Kamimura, Jacomini and Beletti (2010), for goat semen that has not been subjected to the cryopreservation process, the average chromatin fragmentation is $1.54 \pm 0.16 \%$. In the present study an average value was obtained for fragmented chromatin of $2.95 \pm 2.40 \%$, superior to the expected for fresh semen. According to Maia and Bicudo (2009), the cryopreservation process causes oxidative stress on the sperm cell; however, the addition of antioxidants to the freezing and cooling semen medium helps protect the spermatozoa against free radical induced damage because in high concentrations these are harmful to cellular functions and have the ability to damage all types of biomolecules, including DNA, proteins, and lipids. Even so, superior values are expected for cryopreserved semen, as in the present study, of $2.95 \pm 2.40 \%$ for fragmented DNA.

\section{Conclusions}

The inclusion of up to $60 \mathrm{ng} \mathrm{mL}^{-1}$ of DHA in the diluent did not promote any improvement in the seminal quality parameters of postthawed goat semen. It is suggested that further studies be carried out to evaluate, also, the fertilization capacity of post-thaw sperm.

\section{Acknowledgments}

We are grateful to the owners of Fazenda Agropecuária Bantu, for making the animals and the entire physical structure of the farm available for the execution of the field experiment.

\section{References}

Abdi-Benemar, H., Jafaroghli, M., Khalili, B., Zamiri, M. J., Ezazi, H., \& Shadparvar, A. A. (2015). Effects of DHA supplementation of the extender containing egg yolk and $\alpha$ - tocopherol on the freezability and post-thawing fertility of ram semen. Small Ruminant Research, 130, 166-170. doi: 10.1016/j.smallrumres. 2015.06.013

Aguiar, C. S., Barros, C. H. S. C., Machado, W. M., Allaman, I.B., Barbosa, L.P., \&Snoeck, P.P.N. (2020). Efeito doácido docosa-hexaenoico e do Trolox ${ }^{\circ}$ no diluidor de refrigeração de sêmen de garanhões da raça Mangalarga Marchador. Arquivo Brasileiro de Medicina Veterinária e Zootecnia, 72(1), 71-78. doi: 10.1590/1678-4162-10823

Ansari, M., Towhidi, A., Shahrbabak, M. M., \& Bahreini, M. (2012). Docosahexaenoic acid and alpha-tocopherol improve sperm cryosurvival in goat. Slovak Journal of Animal Science, 45(1), 7-13.

Apriokur, J. S. (2013). Pharmacology of free radicals and the impact of reactive oxygen species on the testis. Journal of Reproduction and Infertility, 14(4), 158172.

Beletti, M. E., \& Mello, M. L. S. (2004). Comparison between the toluidina blue stain and the Feulgen reaction for evaluation of rabbit sperm chromatin condensation and their relationship with sperm morphology. Theriogenology, 62(3-4), 398-402. doi: 10.1016/j.theriogenology.2003.10.016 
Bucak, M. N., Sariözkan, S., Tuncer, P. B., Sakin, F., Ateşşahin, A., Kulaksız, R., \& Cevik, M. (2010). The effect of antioxidants on post-thawed Angora goat (Capra hircus ancryrensis) spermparameters, lipid peroxidation and antioxidant activities. Small Ruminant Research, 89(1), 24-30. doi: 10.1016/j. smallrumres.2009.11.015

Cavalcante, T. V., Esper, C. R., \& Ferreira, J. L. (2005). Avaliação da atividade mitocondrial em espermatozóides pós-colheita e pós-descongelação de caprinos das raças boer e alpina durante as estações reprodutiva e não reprodutiva. Archives of Veterinary Science, 10(2), 89-93. doi: 10.5380/avs.v10i2.4422

Colégio Brasileiro de Reprodução Animal (2013). Manual para exame andrológico e avaliação do sêmen animal (3a ed.). Belo Horizonte: CBRA.

Del Valle, I., Souter, A., \& Maxwell, W. M. C. (2013). Function of ram spermatozoa frozen in diluents supplemented with casein and vegetable oils. Animal Reproduction Science, 138(1), 213-219. doi: 10. 1016/j. anireprosci.2013.02.022

Dorado, J., Hidalgo, M., Muñoz, M., \& Rodríguez, I. (2009). Assessment of goat semen freezability according to the spermatozoa characteristics from fresh and frozen sample. Animal Reproduction Science, 112(1-2), 150-157. doi: 10.1016/j. anireprosci.2008.04.005

Flesh, F. M., \& Gadella, B. M. (2000). Dynamics of the mammalian sperm plasma membrane in the process of fertilization. Biochimica et Biophysica Acta, 1469(3), 197-235. doi 10.1016/s0304-4157(00)00018-6

González-Ravina, C., Aguirre-Lipperheide, M., Pinto, F., Martín-Lozano, D., FernándezSánchez, M., Blasco, V.,... Candenas, L. (2018). Effect of dietary supplementation with a highly pure and concentrated docosahexaenoic acid (DHA) supplement on human sperm function. Reproductive Biology, 18(3), 282-288. doi: 10.1016/j. repbio.2018.06.002

Kaka, A., Haron, W., Yusoff, R., Yimer, N., Khumran, A. M., Memon, A. A.,... Ebrahimi, M. (2017). Frozen-thawed quality of bull semen after combined supplementation of docosahexaenoic acid and alpha linolenic acid into tris based semen extender. Pakistan Journal Zoological, 49(6), 2051-2055. doi: 10.17582/ journal. pjz/2017.49.6.2051.2055

Kaka, A., Wahid, H., Rosnina, Y., Khumran, A. M., Sarsaifi, K., Behan, A. A.,... Ebrahimi, M. (2015). $\alpha$-Linolenicacid supplementation in BioXcell ${ }^{\bullet}$ extender can improve the quality of post-cooling and frozen-thawed bovine sperm. Animal Reproduction Science, 153(1), 1-7. doi: 10.1016/j. anireprosci.2014.12.001

Kamimura, C. F., Jacomini, J. O., \& Beletti, M. E. (2010). Alterações de cromatina em 596 espermatozóides de ovinos e caprinos avaliadas por azul de toluidina e alaranjado 597 de acridina. Ciência Agrotecnica, 34(1), 212-219. doi: 10.1590/S141370542010000100027

Losano, J. D. A., Angrimani, D. S. R., Rui, B. R., Bicudo, L. C., Dalmazzo, A., Silva, B. C. S.,... Nichi, M. (2018). The addition of docosahexaenoic acid (DHA) and antioxidants (glutathione peroxidase and superoxide dismutase) in extenders to epididymal sperm cryopreservation in bulls. Zygote, 26(3), 199-206. doi: 10.1017/ S0967199418000096

Machado, W. M., Barbosa, L. P., Souza, R. S., França, C. S., Pinheiro, E. E. G., Lents, M. P.,... Santana, A. L. A. (2018). Óleo de peixe associado ao ácido ascórbico no 
diluidor para criopreservação de sêmen caprino. Arquivo Brasileiro de Medicina Veterinária e Zootecnia, 70(1), 131-138. doi: 10.1590/1678-4162-9506

Maia, M. S., \& Bicudo, S. D. (2009). Radicais livres, antioxidantes e função espermática em mamíferos: uma revisão. Revista Brasileira de Reprodução Animal, 33(1), 183-193.

Maldjian, A., Pizzi, F., Gliozzi, T., Cerolini, S., Penny, P., \& Noble, R. (2005). Changes in sperm quality and lipid composition during cryopreservation of boar semen. Theriogenology, 63(2), 411-421. doi: 10.1016/j. theriogenology.2004.09.021

Marco-Jiménez, F., Viudes-de-Castro, M. P., Balasch, S., Mocé, E., Silvestre,M.A., Gomez, E. A., \& Vicente, J. S. (2006). Morphometric changes in goat sperm heads induced by cryopreservation. Cryobiology, 52(2), 295304. doi: 10.1016/j.cryobiol. 2006.01.002

Nasiri, A. H., Towhidi, A., \& Zeinoaldini, S. (2012). Combined effect of DHA and $\alpha$-tocopherol supplementation during bull semen cryopreservation on sperm characteristics and fatty acid composition. Andrology, 44(1), 550-555. doi: 10.1111/j.1439-0272.2011.01225.x
SPSS Statistics (2015). Programa SPSS Statistics. Command Syntax Reference (versão 23.0). Chicago, IL: SPSS Inc.

Takahashi, T., Itoh, R., Nishinomiya, H., \& Manabe, N. (2012). Effect of linoleic acid albumin in a diluition solution and longterm equilibration for freezing of bovine spermatozoa with poor freezability. Reproduction in Domestic Animal, 47(1), 92-97. doi: 10.1111/ j.14390531.2011.01806.x

Towhidi, A., Zeinoaldini, S., Ardebili, R., Davachi, N. D., \& Nasiri, A. H. (2013). Combined n-3 fatty acids and Ît-Tocopherol supplementation improved the ovine sperm Cryosurvival. Iranian Journal of Biotechnology, 11(4), 238-43. doi: 10.5812/IJB.14469

Tsakmakidis, I. A. (2010). Ram semen evaluation: development and efficiency of modern techniques. Small Ruminant Research, 92(1-3), 126-130. doi: 10.1016/ j.smallrumres.2010.04.017 